\title{
Thyroid hormone effects on androgen receptor messenger RNA expression in rat Sertoli and peritubular cells
}

\author{
N K Arambepola, D Bunick and P S Cooke \\ Department of Veterinary Biosciences, University of Illinois, Urbana, Illinois 61801, USA \\ (Requests for offprints should be addressed to N K Arambepola, Department of Veterinary Biosciences, University of Illinois, 2001 South Lincoln Avenue, \\ Urbana, Illinois 61801, USA)
}

\begin{abstract}
Postnatal Sertoli cell maturation is characterized by a pronounced rise in androgen receptor (AR) expression, which increases several fold between birth and adulthood. Since both 3,3',5-triiodothyronine $\left(\mathrm{T}_{3}\right)$ and FSH regulate Sertoli cell proliferation and differentiation, we have determined the effects of $\mathrm{T}_{3}$ and FSH on AR mRNA expression in cultured Sertoli cells from 5-day-old rats. These cultures contain 5-9\% peritubular cells, which also express AR mRNA. To insure that the observed $\mathrm{T}_{3}$ responses did not result from peritubular cells, we examined $\mathrm{T}_{3}$ effects on AR mRNA expression in cultured 20-day-old Sertoli cells (which contain minimal peritubular contamination) and peritubular cells, and measured thyroid hormone receptor (TR) mRNA expression in both of these cell types. Sertoli cells from 5- and 20-day-old rat testes were grown in serum-free medium alone (controls) or with ovine FSH $(100 \mathrm{ng} / \mathrm{ml})$ and/or $\mathrm{T}_{3}$ (100 nM) for 4 days. Peritubular cells purified from 20day-old rat testes were grown in serum-containing medium for 8 days. These cells were split 1:4, and grown
\end{abstract}

an additional 8 days, the last 4 days in serum-free medium with or without $T_{3}$. TR and AR mRNA levels in all cultures were determined by Northern blotting. AR mRNA levels in 5- and 20-day-old cultured Sertoli cells were significantly $(P<0 \cdot 05)$ increased by both $\mathrm{T}_{3}$ and FSH alone. Furthermore, AR mRNA levels in Sertoli cells treated with $\mathrm{T}_{3}$ and FSH were greater than with either alone. TR mRNA expression was detected in cultured peritubular cells, but TR mRNA levels in these cells were only approximately $30 \%$ of that seen in 20 -day-old cultured Sertoli cells. In contrast to Sertoli cells, $\mathrm{T}_{3}$ did not affect peritubular AR mRNA expression. These results indicate that $T_{3}$ is an important regulator of the postnatal Sertoli cell AR mRNA increase. The additive effects of maximally stimulatory doses of $\mathrm{FSH}$ and $\mathrm{T}_{3}$ suggest these hormones work through different mechanisms to increase AR mRNA. TR mRNA expression in peritubular cells indicates these cells may be direct $T_{3}$ targets, though the function of $\mathrm{T}_{3}$ in these cells is unknown.

Journal of Endocrinology (1998) 156, 43-50

\section{Introduction}

Postnatal Sertoli cell maturation is characterized by steadily increasing androgen receptor (AR) expression, which is barely detectable in these cells at 5 days postnatal but reaches maximal levels by 90 days of age (Bremner et al. 1994, Shan et al. 1995, 1997). Androgens are essential for the initiation of normal spermatogenesis and adult Sertoli cell function (Griswold 1995). This rise in Sertoli cell AR during neonatal and juvenile life may be necessary for the Sertoli cell to achieve full differentiation and androgen responsiveness, resulting in a cell competent to support complete spermatogenesis. The factors which regulate the increase in AR expression during Sertoli cell development are therefore of great importance. Follicle-stimulating hormone (FSH), the major tropic hormone for Sertoli cells (Griswold 1993), increases expression of $A R$ and its mRNA in juvenile Sertoli cells (Sanborn et al. 1984, 1991, Verhoeven \& Cailleau 1988), and androgens also appear to regulate Sertoli cell AR (Shan et al. 1997). However, the overall hormonal mechanisms regulating Sertoli cell AR expression during development are not well understood.

Extensive work in the past few years has indicated that thyroid hormones are major regulators of Sertoli cell development. Transient neonatal hypothyroidism in rats produces unprecedented increases of 80 and $140 \%$ in adult testis weight and sperm production respectively (Cooke \& Meisami 1991, Cooke et al. 1991). This increase in testis size results primarily from increased Sertoli cell proliferation during neonatal and juvenile life (van Haaster et al. 1992) and consequent larger populations of adult Sertoli and germ cells (van Haaster et al. 1992, Hess et al. 1993). Sertoli cells express thyroid hormone receptor (TR) and its mRNA during the neonatal period (Jannini et al. 1990, 1994) and 3,3',5-triiodothyronine $\left(T_{3}\right)$, the biologically active thyroid hormone, directly inhibits Sertoli cell proliferation in vitro (Cooke et al. 1994). $\mathrm{T}_{3}$ also appears to stimulate maturation of Sertoli cells (van Haaster et al. 
1993), and has been shown to directly increase production of Sertoli cell secretory proteins (Cooke et al. 1994, Jannini et al. 1995) and decrease aromatase activity (Panno et al. 1994, Ulisse et al. 1994).

The aim of the present study was to use cultured neonatal Sertoli cells to determine if $T_{3}$ might be involved in the Sertoli cell AR increase during development. These experiments are complicated by the presence of peritubular cells in the cultures, which express high levels of AR neonatally and could make interpretation of the results difficult. Therefore, we also directly evaluated the expression of TR mRNA by cultured peritubular cells and the ability of $\mathrm{T}_{3}$ to regulate AR mRNA in these cells in vitro to determine if these cells had the capacity to directly respond to $\mathrm{T}_{3}$ and whether $\mathrm{T}_{3}$ might also modulate AR mRNA expression in peritubular cells.

\section{Materials and Methods}

Animal purchase, care and breeding were as described previously (Cooke \& Meisami 1991). All experiments described here involving animals were approved by the Laboratory Animal Care Advisory Committee of the University of Illinois, and were conducted in accordance with the Guiding Principles for the Care and Use of Research Animals.

\section{Sertoli cell culture from 5-day-old rats}

Sertoli cells from 5-day-old Sprague-Dawley rats (day of birth $=$ day 0 ) were isolated using a sequential enzymatic procedure that we (Cooke et al. 1994) and others (Rong-Xi et al. 1987, Orth \& Boehm 1990) have described previously. Briefly, for each culture, pools of Sertoli cells were obtained from eight to ten males from two litters. Sertoli cells were grown in 24-well plates coated with Matrigel (Collaborative Research, Waltham, MA, USA) diluted 1:5 with Hank's balanced salt solution. Cells were plated at a density of $4 \times 10^{5}$ cells/well. The nutritive media was Dulbecco's minimum essential medium (DMEM) supplemented with sodium pyruvate $(1 \mathrm{~mm})$, non-essential amino acids $(0 \cdot 1 \mathrm{~mm})$ and an antimicrobial solution (Rong-Xi et al. 1987, Orth \& Boehm 1990). Cells were grown for 4 days in a humidified atmosphere of $95 \%$ air $/ 5 \% \mathrm{CO}_{2}$ at $34{ }^{\circ} \mathrm{C}$. Media was changed every $24 \mathrm{~h}$.

Some cultures were grown without hormonal supplementation, while others received FSH (ovine FSH$18,100 \mathrm{ng} / \mathrm{ml}$ ) and/or $\mathrm{T}_{3}$ (Sigma, St Louis, MO, USA) at $100 \mathrm{~nm}$. In all cases, $\mathrm{T}_{3}$ was added at the initiation of the culture while FSH was added at the beginning of the third day, and fresh hormone was added when media were changed. After 4 days in vitro, some wells of cultured Sertoli cells were used to obtain RNA for Northern analysis. The entire experiment was performed on 10 separate occasions.

\section{Sertoli and peritubular cell culture from 20-day-old rats}

Sertoli and peritubular cells from 20-day-old SpragueDawley rat testes were prepared using procedures that have been described previously (Tung \& Fritz 1977, Buzek \& Sanborn 1990). Briefly, testes were decapsulated in DMEM/Ham's F-12 medium and minced into $0.5 \mathrm{~mm}$ fragments. Testicular fragments were then subjected to enzymatic treatment, as described previously (Tung \& Fritz 1977, Buzek \& Sanborn 1990). The Sertoli cellenriched fragment was then harvested by unit-gravity sedimentation, while the supernatant fraction was used to prepare peritubular cell cultures.

The digested Sertoli cell-enriched fragments were washed with DMEM/Ham's F-12, and the subsequent treatment of the cells was as described for the 5-day-old Sertoli cell isolation procedure (Cooke et al. 1994). Cells were plated at a density of $5 \times 10^{5}$ cells/well. These cells were then cultured under conditions identical to that described above for 5-day-old Sertoli cells, and the cells were similarly subjected to treatment with $\mathrm{FSH}$ and $\mathrm{T}_{3}$ as above. The entire experiment was performed five times.

The peritubular cell-enriched preparation obtained from the collagenase supernatant fraction described above was used to obtain a cell pellet of peritubular cells, as described previously (Tung \& Fritz 1977, Buzek \& Sanborn 1990). This pellet was resuspended in DMEM/ Ham's F-12 containing 1\% BSA and washed. Peritubular cells were plated at a density of $4 \times 10^{5}$ cells/well and grown in a humidified atmosphere of $95 \%$ air $/ 5 \% \mathrm{CO}_{2}$ at $34{ }^{\circ} \mathrm{C}$ on $24-w e l l$ plates coated with Matrigel, as described for 5-day-old Sertoli cells. The nutritive medium was the same as used for Sertoli cells, but supplemented with $10 \%$ fetal calf serum (Sigma); medium was changed every 2 days. Cells were grown for 8 days, then removed from their substrate using trypsin $(0 \cdot 25 \%)$, split $1: 4$ and replated into 24-well plates as above. Cells were grown an additional 4 days in serum-containing medium, then cultured for 4 days without serum and either with or without $T_{3}(100 \mathrm{~nm})$. The data shown are based on five separate isolation procedures.

\section{Viability and purity of cultured cells}

For all cell cultures described, the percentage of viable cells was determined by trypan blue exclusion before plating. To assess contamination with other cell types, cultures were examined daily using an inverted microscope. In addition, at the end of the culture, wells of all cell types were stained for alkaline phosphatase or $3 \beta$-hydroxysteroid dehydrogenase $(3 \beta-\mathrm{HSD})$, which are markers for peritubular and Leydig cells respectively (Chapin et al. 1987, Orth \& Boehm. 1990, Cooke et al. 1994). Since Leydig 
cells differentiate during early postnatal life and may not stain as intensely for $3 \beta-\mathrm{HSD}$ during this period as fully mature adult Leydig cells, both intensely and weakly stained cells were scored as positive.

\section{Northern analysis}

Total RNA was prepared from all cell cultures using the RNeasy Mini Kit (Qiagen, Chatsworth, CA, USA). Total RNA was also isolated from 20-day-old testis and adult spleen, which served as positive and negative controls respectively, for the various probes. Purified total RNA was dissolved in diethylpyrocarbonate (DEPC)-treated water. Purity and concentration of the RNA were determined by UV $(260 / 280 \mathrm{~nm})$ absorbance in a spectrophotometer. Equal amounts of total RNA $(8 \mu \mathrm{g})$ from the various treatment groups were electrophoresed on a $1.5 \%$ agarose formaldehyde gel. The gel was blotted to nylon membrane and the RNA fixed to the membrane by UV cross linking.

The following probes were used in this study: 1) c-erbAa, a probe which detects both TR $\alpha 1$ and $\alpha 2$ mRNA (Murry et al. 1988), 2) rat antigen binding protein (ABP) (Joseph et al. 1987), 3) rat AR (Chang et al. 1988) and 4) human 28S rRNA (Erickson \& Schimickel 1985). Initial Northern studies of AR mRNA expression were performed with the full-length $2.83 \mathrm{~kb}$ AR cDNA construct, while later experiments were performed using a $1.15 \mathrm{~kb}$ AR cDNA fragment (Chang et al. 1988). Both probes recognized the $9.5 \mathrm{~kb}$ AR mRNA transcript (Chang et al. 1988). Insert for each cDNA probe was isolated from the plasmid vector by restriction digestion and gel purification. Each insert was labeled with ${ }^{32} \mathrm{P}$-dCTP using the Multiprime DNA labeling system (Amersham, Arlington Heights, IL, USA) and used to probe the membrane.

All hybridizations were carried out in QuikHyb (Stratagene, La Jolla, CA, USA) according to manufacturer's recommendations at $68{ }^{\circ} \mathrm{C}$ in a Robbins scientific hybridization oven (Sunnyvale, CA, USA). The hybridized membrane was washed, covered with plastic wrap and exposed to Kodak X-omat X-ray film with intensifying screens. After hybridization with the TR $\alpha$ cDNA probe, membranes were stripped of probe by incubation in $50 \%$ formamide at $65{ }^{\circ} \mathrm{C}$ for $1 \mathrm{~h}$ and then rehybridized with the AR cDNA probe. These Northern blots were also rehybridized with the ABP cDNA probe. For normalization of RNA load levels between lanes, the membrane was reprobed for a final time with labeled $28 \mathrm{~S}$ rRNA cDNA probe.

The mRNA bands on the autoradiograms were scanned and quantitated using a computer-linked scanning laser densitometer and RFLPrint software (Pdi, Huntington Station, NY, USA). Relative levels of mRNA transcripts were adjusted to compensate for differences in total RNA loaded per gel lane as determined by densitometry of $28 \mathrm{~S}$

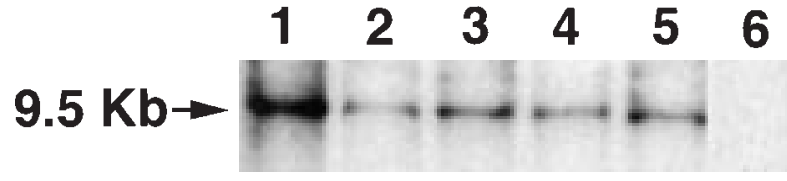

Figure 1 Northern blot detection of steady-state AR mRNA. A $9.5 \mathrm{~kb}$ transcript was detected in 20-day-old testis (lane 1) and Sertoli cells from 5-day-old rats cultured 4 days without hormonal supplementation (lane 2), with $100 \mathrm{nM} \mathrm{T}_{3}$ (lane 3), with $100 \mathrm{ng} / \mathrm{ml}$ FSH (lane 4), or with FSH and $\mathrm{T}_{3}$ (lane 5). A negative control, spleen, is also shown (lane 6).

rRNA hybridization signals (Bunick et al. 1994). All statistical analyses were performed using the SYSTAT statistical package (Wilkinson 1990). The optical densities (OD) of the bands in the various treatment groups were compared by two-way ANOVA, and differences between various treatment groups were compared using Tukey's HSD test. Differences were considered significant when $P<0 \cdot 05$.

\section{Results}

\section{Characterization of Sertoli and peritubular cell cultures}

Trypan blue exclusion experiments indicated that more than $95 \%$ of the isolated peritubular and Sertoli cells were viable. The Sertoli cell cultures from the 5-day-old rats had a morphology typical of Sertoli cells in vitro (Cooke et al. 1994). Approximately $5 \%$ of the cells were peritubular, as judged by their morphology and positive alkaline phosphatase staining, while Leydig cell contamination was minimal $(<1 \%)$. The Sertoli cell cultures from the 20-day-old rats also showed a very low level of Leydig and peritubular cell contamination $(<1 \%)$. Primary peritubular cell cultures consisted predominately of fibroblastic cells; small numbers of Sertoli cells could also be identified by their nuclear morphology and cell shape. However, after the peritubular cells were passaged, Sertoli cells were absent and cultures consisted exclusively of fibroblastic cells. Alkaline phosphatase staining was very strong in peritubular cell cultures, while less than $1 \%$ of the cells stained for $3 \beta-\mathrm{HSD}$, indicating minimal Leydig cell contamination.

\section{Expression of $A R$ and TR $m R N A$ in Sertoli cell cultures from 5-day-old rats}

In Northern blots for AR (Fig. 1), a $9.5 \mathrm{~kb}$ band which has previously been shown to correspond to AR mRNA (Chang et al. 1988, Sanborn et al. 1991, Shan et al. 1995) was detected in cultured Sertoli cells from 5-day-old rats. AR mRNA was also detected in 20-day-old rat testis, a positive control, but not in spleen, a negative control which lacks detectable AR mRNA (Shan et al. 1995). Densitometric analysis of hybridization results (Fig. 2) 




Figure 2 Normalized densitometric data of AR mRNA expression by 5 -day-old Sertoli cells cultured 4 days with or without hormonal supplementation, as in Fig. 1. Signals were normalized against a $28 \mathrm{~S}$ rRNA cDNA probe to compensate for interlane differences in RNA loading. The values for each of the treatment groups were expressed as a fold increase relative to the control, and the data are presented as means \pm S.E.M. of values from 10 separate experiments. The mean values for all treatment groups were different from each other $(P<0 \cdot 05)$ with the exception of the groups treated with $\mathrm{FSH}$ or $\mathrm{T}_{3}$ alone, which did not differ.

indicated that steady-state levels of AR mRNA expression in cells treated with $\mathrm{T}_{3}$ or FSH alone were both slightly under 2-fold that of the untreated controls $(P<0.05$ for both compared with controls). AR mRNA expression in cells treated with both of these hormones was approximately $2 \cdot 5$-fold that of control cultures, indicating that $T_{3}$ and FSH acted additively to increase AR mRNA expression to a level greater than with either hormone alone. Cultured 5-day-old Sertoli cells also expressed relatively high levels of TR $\alpha 1$ and $\alpha 2$ mRNA (data not shown).

Expression of $A R, T R$ and $A B P m R N A$ in Sertoli and peritubular cell cultures from 20-day-old rats

Hormonal regulation of AR mRNA expression in 20-dayold Sertoli cells (Fig. 3) was similar to that in 5-day-old Sertoli cells. Normalized densitometric data (Fig. 4) indicated that $\mathrm{T}_{3}, \mathrm{FSH}$, or $\mathrm{T}_{3}$ and FSH significantly $(P<0 \cdot 05)$ stimulated steady-state AR mRNA expression above control levels. The $\mathrm{T}_{3}$ and FSH response was greater than that seen with either hormone alone, and the $\mathrm{T}_{3}$ and $\mathrm{FSH}$ groups were not significantly different. In some cases, RNA from both 5- and 20-day-old Sertoli cell cultures were run on the same Northern blot, which allowed a direct comparison of mRNA levels of $\mathrm{AR}$ in the various

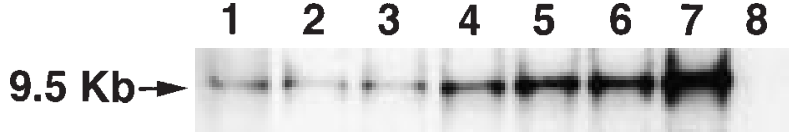

Figure 3 Northern blot detection of steady-state AR mRNA in testis, spleen and cultured testicular cells. A $9.5 \mathrm{~kb}$ transcript was detected in whole 20-day-old testis (lane 1). Peritubular cells from 20-day-old rats were grown for 16 days as described in the text; the last 4 days these cells were cultured either without (lane 2) or with (lane 3) $100 \mathrm{nM} \mathrm{T}_{3}$. Sertoli cells from 20-day-old rats were cultured 4 days without hormonal supplementation (lane 4), with $100 \mathrm{nM} \mathrm{T}_{3}$ (lane 5), with $100 \mathrm{ng} / \mathrm{ml} \mathrm{FSH}$ (lane 6), or with FSH and $\mathrm{T}_{3}$ (lane 7). Spleen (lane 8), which was used as a negative control, did not contain detectable levels of AR mRNA.

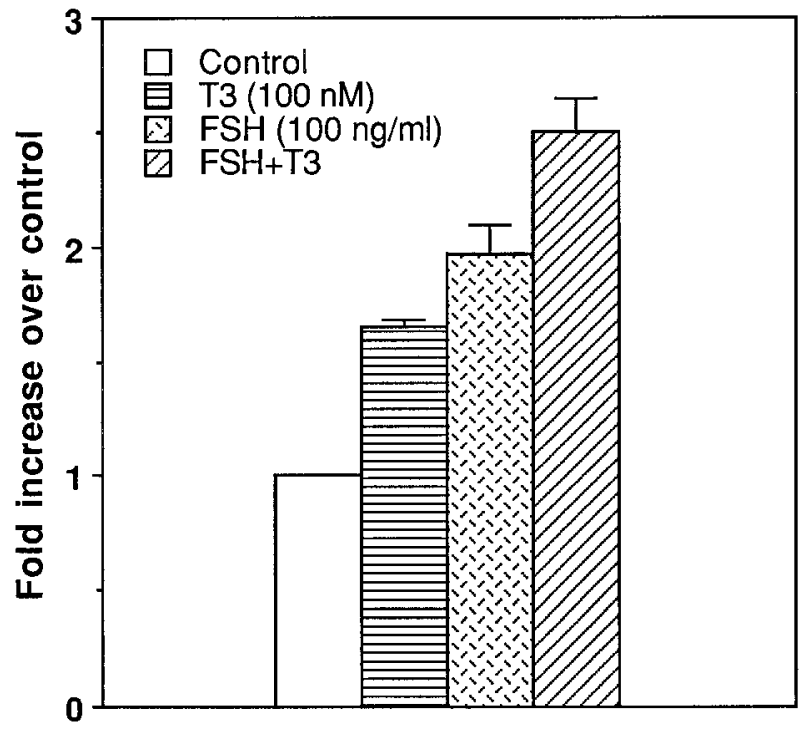

Figure 4 Normalized densitometric data of AR mRNA expression by 20 -day-old Sertoli cells cultured 4 days with or without hormonal supplementation, as in Fig. 3. Signals were normalized against a $28 \mathrm{~S}$ rRNA cDNA probe to compensate for interlane differences in RNA loading. The values for each of the treatment groups were expressed as a fold increase relative to the control, and the data are presented as means \pm S.E.M. of values from five separate experiments. As in Fig. 2, the mean values for all treatment groups were different from each other $(P<0 \cdot 05)$ with the exception of the groups treated with $\mathrm{FSH}$ or $\mathrm{T}_{3}$ alone, which did not differ.

groups. These results indicated that 20-day-old Sertoli cells expressed approximately 2-fold more AR mRNA than 5 -day-old cells from the same treatment group (not shown).

Although AR mRNA could be clearly detected in peritubular cell cultures, $\mathrm{T}_{3}$ treatment did not have a significant effect on the steady-state AR mRNA level (Fig. 3), a conclusion confirmed by analysis of the normalized densitometric data (not shown). Thus, $\mathrm{T}_{3}$ does not appear to stimulate AR mRNA in cultured peritubular cells as it does in Sertoli cells.

Northern blotting for TR mRNA in Sertoli cell cultures from 20-day-old rats indicated that they strongly 


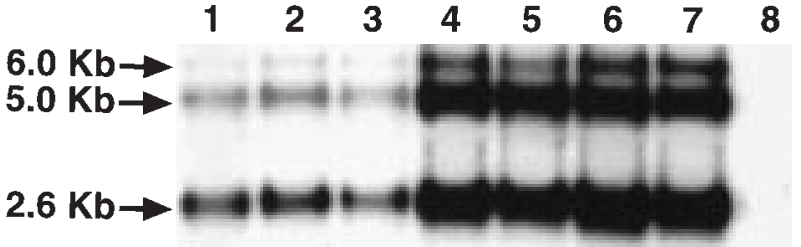

Figure 5 Northern blot detection of steady-state TR mRNA. The probe used recognizes both the TR $\alpha 1(5.0 \mathrm{~kb})$ and TR $22(2.6 \mathrm{~kb})$ forms of TR $\alpha$. A minor $6.0 \mathrm{~kb}$ band, thought to represent unprocessed heteronuclear RNA encoding unspliced primary transcripts of RNA prior to their processing into the mature $\alpha 1$ and $\alpha 2$ mRNAs, is also seen (Williams 1994). TR $\alpha 1$ and TR 2 mRNA were detected in 20-day-old testis (lane 1) and in peritubular cells from 20-day-old rats cultured the last 4 days either without (lane 2) or with (lane 3) $100 \mathrm{nM} \mathrm{T}_{3}$, as in Fig. 3. Sertoli cells from 20-day-old rats cultured 4 days without hormonal supplementation (lane 4), with $100 \mathrm{nM} \mathrm{T}_{3}$ (lane 5), with $100 \mathrm{ng} / \mathrm{ml}$ $\mathrm{FSH}$ (lane 6), or with FSH and $\mathrm{T}_{3}$ (lane 7) all expressed TR $\alpha 1$ and TR 22 mRNA. Conversely, spleen (lane 8 ) did not. Analysis of normalized densitometric data indicated that TR mRNA expression by cultured peritubular cells was approximately $30 \%$ of that in Sertoli cells.

expressed TR $\alpha 1$ and $\alpha 2$ mRNA (Fig. 5). However, TR $\alpha 1$ and $\alpha 2$ mRNA expression was not significantly different in the 5- or 20-day-old Sertoli cells or amongst the different treatment groups at these ages. Therefore, in contrast to the results obtained with AR mRNA, neither FSH nor $\mathrm{T}_{3}$ treatment nor age of the Sertoli cells used had a significant effect on the steady-state levels of TR $\alpha 1$ and $\alpha 2$ mRNA.

TR $\alpha$ mRNA was also detected in freshly isolated peritubular cells from 20-day-old rats (data not shown) and in these peritubular cells following 16 days of culture (Fig. 5). Both TR $\alpha 1$ and $\alpha 2$ mRNA were detected in cultured peritubular cells and the relative abundance of the TR $\alpha 2$ mRNA was approximately 2 -fold greater than that for TR $\alpha 1$ in both the peritubular and Sertoli cells. TR $\alpha$ mRNA expression in peritubular cells was less than in Sertoli cells; in the control cultures, the relative abundance of TR $\alpha 1$ and $\alpha 2$ mRNA per $\mu$ g of RNA was about 3-fold greater in cultured 20-day-old Sertoli cells compared with 20-day-old peritubular cells (data not shown).

Expression of ABP mRNA in peritubular cell cultures was not detectable, in stark contrast to the 20-day-old Sertoli cell cultures, in which ABP mRNA was strongly expressed (Fig. 6). Therefore, Sertoli cell contamination is minimal in the peritubular cell cultures.

\section{Discussion}

Sertoli cell AR is barely detectable by immunohistochemistry in 5-day-old neonatal rats (Bremner et al. 1994). AR concentration per Sertoli cell then increases during juvenile life, reaching maximal levels during adulthood (Buzek et al. 1987, Buzek \& Sanborn 1988, Shan et al.

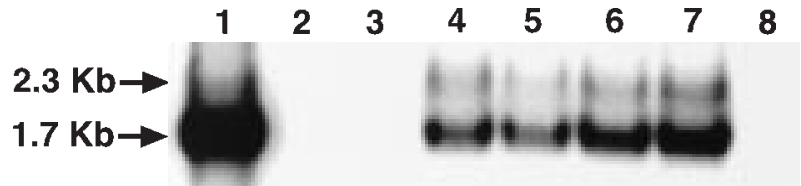

Figure 6 Northern blot detection of steady-state ABP mRNA. Two ABP mRNA bands were detected in 20-day-old testis (lane 1). These bands, a major $1.7 \mathrm{~kb}$ ABP transcript and a minor $2.3 \mathrm{~kb}$ transcript, correspond to the sizes of the ABP transcripts reported previously (Joseph et al. 1987, Bunick et al. 1994). Peritubular cells from 20-day-old rats cultured the last 4 days either without (lane 2) or with (lane 3) $100 \mathrm{nM} \mathrm{T}_{3}$ (as in Fig. 3) did not express detectable ABP mRNA, indicating that Sertoli cell contamination in these cultures was minimal. Sertoli cells from 20-day-old rats cultured 4 days without hormonal supplementation (lane 4), with $100 \mathrm{nM} \mathrm{T}_{3}$ (lane 5), with $100 \mathrm{ng} / \mathrm{ml} \mathrm{FSH}$ (lane 6), or with FSH and $\mathrm{T}_{3}$ (lane 7) all expressed high levels of $\mathrm{ABP}$ mRNA. Spleen (lane 8) did not contain detectable ABP mRNA.

1997). The rise in Sertoli cell AR expression closely parallels that in Sertoli cell AR mRNA expression. For example, Sertoli cells show a 2-fold rise in both AR and AR mRNA between day 21 and adulthood (Shan et al. 1995, 1997).

The present results indicate that $\mathrm{T}_{3}$ treatment results in increased AR mRNA expression in cultured Sertoli cells from 5-day-old rats and may be an important endocrine regulator of the developmental increase in Sertoli cell AR in vivo. Recent work has also indicated that $\mathrm{T}_{3}$ increases androgen binding in cultured juvenile rat Sertoli cells (Panno et al. 1996). Our results suggest that the increased AR levels observed in this study in response to $T_{3}$ result from an increase in AR mRNA steady-state levels rather than changes in translation.

The mechanism by which $T_{3}$ treatment increases AR mRNA expression is not clear. $T_{3}$ has previously been shown to cause a number of changes which are associated with increasing maturation in the neonatal Sertoli cell, such as decreased proliferation, increased production of secretory proteins, and active proluminal secretion of fluid (Francavilla et al. 1991, van Haaster et al. 1993, Cooke et al. 1994). It therefore seems likely that the increases in steady-state AR mRNA levels may reflect general stimulatory effects of $T_{3}$ on Sertoli cell maturation rather than a specific, direct effect of $\mathrm{T}_{3}$ on AR mRNA production, though the latter possibility can not be totally excluded.

The present results are the first demonstration that FSH stimulates AR mRNA expression in Sertoli cells of neonatal rats. In addition, although the stimulatory effects of FSH on AR mRNA in juvenile Sertoli cells have been shown (Sanborn et al. 1991), the present results are the first to show that the combined effects of $\mathrm{T}_{3}$ and $\mathrm{FSH}$ on AR mRNA in neonatal and juvenile Sertoli cells are greater than with either alone. The additive effects of $\mathrm{T}_{3}$ and $\mathrm{FSH}$ suggest that these hormones are not causing their effects through the same pathway, a conclusion consistent with 
previous observations that $T_{3}$ and $\mathrm{FSH}$ effects on other Sertoli cell parameters, such as production of mRNA for an inhibin subunit, are also additive (Cooke et al. 1994).

Testosterone also affects AR expression in postnatal Sertoli cells (Verhoeven \& Cailleau 1988, Sanborn et al. 1991). Therefore, it appears that a number of hormones, including $\mathrm{T}_{3}, \mathrm{FSH}$ and testosterone, and possibly other hormones as well, are necessary for the normal postnatal rise in Sertoli cell AR expression. Additional studies on the role of all of these hormones, alone and especially in combination, will be necessary to obtain a complete understanding of the factors that control Sertoli cell AR mRNA expression, the overall developmental sequence of postnatal Sertoli cell maturation, and the onset of functional activity in these cells.

One possible complication of using Sertoli cell cultures from early postnatal rats is that they contain significant peritubular cell contamination. Schlatt et al. (1996) showed that Sertoli cell cultures from 7-day-old rats contain approximately $6 \%$ peritubular cells after 3 days of culture, and $9 \%$ peritubular cells by the seventh day of culture. Peritubular cell AR expression exceeds that of Sertoli cells in 5-day-old rats (Bremner et al. 1994), indicating that even low levels of contaminating peritubular cells in these cultures could significantly affect total AR measurements. Therefore, data showing effects of $\mathrm{T}_{3}$ on $\mathrm{AR}$ or its mRNA, such as our Northern results with Sertoli cells from 5-day-old rats and previous androgen binding data obtained from Sertoli cells derived from 2-week-old rats (Panno et al. 1996), must be interpreted cautiously.

Sertoli cell cultures from 20-day-old rats have been reported to contain less than $1 \%$ peritubular cell contamination (Raychoudhury et al. 1993), in contrast to the 5-9\% peritubular contamination seen in neonatal Sertoli cell preparations (Cooke et al. 1994, Schlatt et al. 1996). The ability to obtain purer cultures with juvenile rat Sertoli cells allows the potentially confounding effects of peritubular cells to be minimized. Therefore, to obtain unequivocal information on regulation of AR mRNA in Sertoli cells, we also examined the effects of $\mathrm{T}_{3}$ and $\mathrm{FSH}$ on AR mRNA expression in 20-day-old Sertoli cells.

The effects of $\mathrm{T}_{3}$ and $\mathrm{FSH}$, alone and in combination, on AR mRNA expression in the 20-day-old Sertoli cell cultures were similar to that seen in the 5-day-old cultures. These results, obtained in cultures where peritubular cell contamination is minimal, strongly suggest that the stimulatory effects of $\mathrm{T}_{3}$ and $\mathrm{T}_{3}$ and FSH seen in the 5 -day-old Sertoli cell cultures were due to the effects of these hormones on the Sertoli cells themselves, rather than effects on the contaminating peritubular cells in these cultures. In addition, the 20-day-old Sertoli cells expressed approximately twice the AR mRNA of their 5-day-old counterparts, consistent with previous data suggesting a rise in AR between the neonatal and juvenile periods (Buzek et al. 1987, Bremner et al. 1994).
Previous work has indicated that TR $\alpha 1$ and $\alpha 2$ mRNA are produced at high levels in the testis and Sertoli cells neonatally. This expression declines with advancing age, reaching relatively low levels during adulthood (Jannini et al. 1990, 1994, Bunick et al. 1994). The major functional form of TR in the developing testis and Sertoli cells is TR $\alpha 1$. The other major functional TR, TR $\beta 1$, can only be detected in Sertoli cells by PCR techniques (Jannini et al. 1994, Palmero et al. 1995), indicating very low abundance. TR $\alpha 2$ (also called c-erbA $\alpha 2$ ) is a splicing variant of the TR $\alpha$ locus, and does not bind $\mathrm{T}_{3}$ despite its very high homology to $\mathrm{TR} \alpha 1$. Thus, $\mathrm{TR} \alpha 2$ is not a receptor in the strict sense. The function of $T R \alpha 2$ is unknown, though it may have an inhibitory effect on thyroid hormone action (Williams 1994).

If peritubular cells were indeed contributory to the increase in AR mRNA in response to $T_{3}$ seen in Sertoli cell-enriched cultures from 5-day-old rats, peritubular cells would be expected to express TR mRNA and show increased $A R$ mRNA expression when exposed to $T_{3}$ in vitro. We therefore directly evaluated TR mRNA expression and $\mathrm{T}_{3}$ effects on AR mRNA production in 20-day-old peritubular cell cultures. Peritubular cells from 20-day-old rats were used because the small size of the 5-day-old rat testis makes it difficult to obtain sufficient peritubular cells to perform Northern blotting experiments. In addition, well-defined protocols for the purification, culture and assessment of 20-day-old peritubular cells are available (Tung \& Fritz 1977, Sanborn et al. 1991).

Our results indicate that cultured 20-day-old peritubular cells expressed both TR $\alpha 1$ and TR $\alpha 2$ mRNA. However, overall levels of TR $\alpha 1$ and $\alpha 2$ mRNA per $\mu \mathrm{g}$ of RNA in cultured peritubular cells were only about $30 \%$ of the levels in Sertoli cells cultured from 20-day-old rats. Although initial reports indicated that TR was present only in Sertoli cells of the testis and could not be detected in other cell types by either classical $\mathrm{T}_{3}$ binding assays (Jannini et al. 1990) or in situ hybridization for TR mRNA (Jannini et al. 1994), Hardy et al. (1996) recently reported that TR $\alpha 1$ and $\alpha 2$ mRNA could be detected in immature and adult Leydig cells, as well as their juvenile mesenchymal precursors. These data and the present results with peritubular cells suggest that TR may be ubiquitous in the cell types of the developing testis, although levels in these other cell types during development are less than in Sertoli cells (Hardy et al. 1996). Thus, a complete determination of the role of thyroid hormones in the testis will require an understanding of the effects of thyroid hormone on all of these cell types both during development and adulthood.

One potential complication of measuring TR mRNA in peritubular cell cultures is that the strong expression of TR and its mRNA by young rat Sertoli cells (present results and Jannini et al. 1990, 1994) suggests that even low-level Sertoli cell contamination in peritubular cell 
cultures would result in detectable TR mRNA expression. Sertoli cells produce large amounts of ABP, while Leydig and peritubular cells do not produce this protein (Pelliniemi et al. 1981). ABP therefore functions as a specific and sensitive marker for Sertoli cell contamination in peritubular cell cultures. The lack of detectable ABP mRNA in the cultured peritubular cells indicated that Sertoli cell contamination was minimal in the peritubular cell cultures. Therefore, peritubular cells themselves, rather than contaminating Sertoli cells, produce the TR mRNA detected in these cultures.

The expression of TR mRNA in peritubular cell cultures indicates that thyroid hormones could have direct effects on these cells, but $\mathrm{T}_{3}$ did not increase AR mRNA in cultured peritubular cells. Thus, $\mathrm{T}_{3}$ regulates $\mathrm{AR}$ mRNA in Sertoli, but not peritubular cells, a finding similar to what has been previously reported for the effects of FSH on AR mRNA expression in these two cell types (Sanborn et al. 1991). The role of $T_{3}$ in peritubular cells is presently unknown. Mendis-Handagama \& Sharma (1994) reported an increase of approximately 50\% in connective cells (which included peritubular myoid cells as well as other cells such as pericytes and fibroblasts) in adult testes of rats that had been made hypothyroid during neonatal life compared with age-matched untreated controls. These results suggest that $\mathrm{T}_{3}$ may have an effect on the proliferation of peritubular cells, as it does in Sertoli cells (Cooke et al. 1994). Likewise, an effect of $\mathrm{T}_{3}$ on peritubular cell differentiation is also plausible, based on similar effects in Sertoli cells. Peritubular cells communicate extensively with other testicular cell types such as Sertoli and Leydig cells (Skinner 1991) suggesting that in addition to possible direct $\mathrm{T}_{3}$ effects, $\mathrm{T}_{3}$ binding to $\mathrm{TR}$ in peritubular cells could also result in effects on other cell types in the testis through the production of paracrine factors by peritubular cells.

\section{Acknowledgements}

This work was supported by NIH grants HD-29376 (to P S C) and HD-285963 (to D B). The authors thank the National Hormone and Pituitary Program and the USDA Animal Hormone Program for providing the FSH used in these studies. The assistance of David Buchanan in preparing the figures and the statistical expertise provided by Dr David Schaeffer are also gratefully acknowledged. The authors thank Dr H Towle for the c-erbA $\alpha$ cDNA probe, Dr S Liao for the AR cDNA probe and Dr M Griswold for the ABP cDNA probe.

\section{References}

Bremner WJ, Millar MR, Sharpe RM \& Saunders PTK 1994 Immunohistochemical localization of androgen receptor in the rat testis: evidence for stage-dependent expression and regulation by androgens. Endocrinology 135 1227-1234.
Bunick D, Kirby JD, Hess RA \& Cooke PS 1994 Developmental expression of testis mRNAs in the rat following propylthiouracilinduced neonatal hypothyroidism. Biology of Reproduction $\mathbf{5 1}$ 706-713.

Buzek SW \& Sanborn BM 1988 Increase in testicular androgen receptor during sexual maturation in the rat. Biology of Reproduction $3939-49$.

Buzek SB \& Sanborn BM 1990 Nuclear androgen receptor dynamics in testicular peritubular and Sertoli cells. Journal of Andrology 11 514-519.

Buzek SW, Caston LA \& Sanborn BM 1987 Evidence for agedependent changes in Sertoli cell androgen receptor concentration. Journal of Andrology 8 83-90.

Chang CS, Kokontis J \& Liao ST 1988 Structural analysis of complementary DNA and amino acid sequences of human and rat androgen receptors. Proceedings of the National Academy of Sciences of the USA 85 7211-7215.

Chapin RE, Phelps JL, Miller BE \& Gray TJB 1987 Alkaline phosphatase histochemistry discriminates peritubular cells in primary rat testicular cell culture. Journal of Andrology 8 155-161.

Cooke PS \& Meisami E 1991 Early postnatal hypothyroidism causes increased adult size of testis and other reproductive organs but does not increase testosterone levels. Endocrinology 129 237-243.

Cooke PS, Hess RA, Porcelli J \& Meisami E 1991 Increased sperm production in adult rats following transient neonatal hypothyroidism. Endocrinology 129 244-248.

Cooke PS, Zhao Y-D \& Bunick D 1994 Triiodothyronine inhibits proliferation and stimulates differentiation of cultured neonatal Sertoli cells: possible mechanism for increased adult testis weight and sperm production induced by neonatal goitrogen treatment. Biology of Reproduction 51 1000-1005.

Erickson JM \& Schimickel RD 1985 A molecular basis for discrete size variation in human ribosomal DNA. American Journal of Human Genetics 37 311-325.

Francavilla S, Cordeschi G, Properzi G, Di Cicco L, Jannini EA, Palmero S, Fugassa E, Loras B \& D'Armiento M 1991 Effect of thyroid hormone on the pre- and post-natal development of the rat testis. Journal of Endocrinology 129 35-42.

Griswold MD 1993 Actions of FSH on mammalian Sertoli cells. In The Sertoli Cell, pp 509-516. Eds LD Russell \& MD Griswold. Clearwater, FL: Cache River Press.

Griswold MD 1995 Interactions between germ cells and Sertoli cells in the testis. Biology of Reproduction 52 211-216.

van Haaster LH, de Jong FH, Docter R \& de Rooij DG 1992 The effect of hypothyroidism on Sertoli cell proliferation and differentiation and hormone levels during testicular development in the rat. Endocrinology 131 1574-1576.

van Haaster LH, de Jong FH, Docter R \& de Rooij DG 1993 High neonatal triiodothyronine levels reduce the period of Sertoli cell proliferation and accelerate tubular lumen formation in the rat testis, and increase serum inhibin levels. Endocrinology 133 755-760.

Hardy MP, Sharma RS, Arambepola N, Sottas CM, Russell LD, Bunick D, Hess RA \& Cooke PS 1996 Increased proliferation of Leydig cells induced by neonatal hypothyroidism in the rat. Journal of Andrology 17 231-238.

Hess RA, Cooke PS, Bunick D \& Kirby JD 1993 Adult testicular enlargement induced by neonatal hypothyroidism is accompanied by increased Sertoli and germ cell numbers. Endocrinology 132 2607-2613.

Jannini EA, Olivieri M, Francavilla S, Gulino A, Ziparo E \& D'Armiento M 1990 Ontogenesis of nuclear 3,5,3'-triiodothyronine receptor in the rat testis. Endocrinology 126 2521-2526.

Jannini EA, Dolci S, Ulisse S \& Nikodem VM 1994 Developmental regulation of the thyroid hormone receptor $\alpha 1$ mRNA expression in rat testis. Molecular Endocrinology 8 89-96.

Jannini EA, Ulisse S \& D’Armiento M 1995 Thyroid hormone and male gonadal function. Endocrine Review 16 443-459. 
Joseph DR, Hall SH \& French FS 1987 Rat androgen-binding protein: evidence for identical subunits and amino acid sequence homology with human sex hormone-binding globulin. Proceedings of the National Academy of Sciences of the USA 84 339-343.

Mendis-Handagama SM \& Sharma OP 1994 Effects of neonatal administration of the reversible goitrogen propylthiouracil on the testis interstitium in adult rats. Journal of Reproduction and Fertility 100 85-92.

Murry MB, Zilz ND, McCreary NL, Mac Donald MJ \& Towle HC 1988 Isolation and characterization of rat cDNA clones for two distinct thyroid hormone receptors. Journal of Biological Chemistry $26312770-12777$.

Orth JM \& Boehm R 1990 Functional coupling of neonatal rat Sertoli cells and gonocytes in coculture. Endocrinology 127 2812-2820.

Palmero S, De Marco P \& Fugassa E 1995 Thyroid hormone receptor $\beta$ mRNA expression in Sertoli cells isolated from prepubertal testis. Journal of Molecular Endocrinology 14 31-34.

Panno ML, Beraldi E, Pezzi V, Salerno M, De Luca G, Lanzino M, Lepera M, Sisci D, Prati M, Palmero S, Bolla E, Fugassa E \& Ando S 1994 Influence of thyroid hormone on androgen metabolism in peripubertal rat Sertoli cells. Journal of Endocrinology 140 349-355.

Panno ML, Sisci D, Salerno M, Lanzino M, Pezzi V, Morrone EG, Mauro L, Palmero S, Fugasso E \& Ando S 1996 Thyroid hormone modulates androgen and oestrogen receptor content in the Sertoli cells of peripubertal rats. Journal of Endocrinology 148 43-50.

Pelliniemi LJ, Dym M, Gunsalus GL, Musto NA, Bardin CW \& Fawcett DW 1981 Immunocytochemical localization of androgen-binding protein in the male rat reproductive tract. Endocrinology 108 925-931.

Raychoudhury SS, Thompson EW, Blackshaw AW \& Irving MG 1993 Sertoli cells as paracrine modulators of DNA synthesis in rat peritubular myoid cells in culture. Journal of Reproduction and Fertility 99 513-518.

Rong-Xi D, Djakiew D \& Dym M 1987 Endocytic activity of Sertoli cells grown in bicameral culture chambers. Anatomical Records $\mathbf{2 1 8}$ 306-312.
Sanborn BM, Wagle JR \& Steinberger A 1984 Control of androgen cytosol receptor concentrations in Sertoli cells: effects of androgens. Endocrinology $1142388-2392$.

Sanborn BM, Caston LA, Chang C, Liao S, Speller R, Porter LD \& Ku CY 1991 Regulation of androgen receptor mRNA in rat Sertoli and peritubular cells. Biology of Reproduction 45 634-641.

Schlatt S, de Kretser DM \& Loveland KL 1996 Discriminative analysis of rat Sertoli and peritubular cells and their proliferation in vitro: evidence for follicle stimulating hormone-mediated contact inhibition of Sertoli cell mitosis. Biology of Reproduction 55 227-235.

Shan L-X, Zhu L-J, Bardin CW \& Hardy MP 1995 Quantitative analysis of androgen receptor messenger ribonucleic acid in developing Leydig cells and Sertoli cells by in situ hybridization. Endocrinology 136 3856-3862.

Shan L-X, Bardin CW \& Hardy MP 1997 Immunohistochemical analysis of androgen effects on androgen receptor expression in developing Leydig and Sertoli cells. Endocrinology 138 1259-1266.

Skinner MK 1991 Cell-cell interactions in the testis. Endocrine Review 12 45-77.

Tung PS \& Fritz IB 1977 Sertoli cell-enriched preparation. In Techniques of Human Andrology, pp 125-143. Ed ESE Hafez. Amsterdam: Elsevier/North Holland Biomedical Press.

Ulisse S, Jannini EA, Carosa E, Piersanti D, Graziano FM \& D'Armiento M 1994 Inhibition of aromatase activity in rat Sertoli cells by thyroid hormone. Journal of Endocrinology 140 431-436.

Verhoeven G \& Cailleau J 1988 Follicle-stimulating hormone and androgens increase the concentration of the androgen receptor in Sertoli cells. Endocrinology 122 1541-1550.

Wilkinson L 1990 SYSTAT: The System for Statistics. Evanston, IL: SYSTAT, Inc.

Williams GR 1994 Thyroid Hormone Regulation of Gene Expression. Austin, TX: RG Landes Company.

Received 20 May 1997

Accepted 7 August 1997 